\title{
Article \\ Impacts of Governance toward Sustainable Urbanization in a Midsized City: A Case Study of Uyo, Nigeria
}

\author{
Etido Essien (D)
}

Citation: Essien, E. Impacts of Governance toward Sustainable Urbanization in a Midsized City: A Case Study of Uyo, Nigeria. Land 2022, 11, 37. https://doi.org/ 10.3390/land11010037

Academic Editors: Antonio Sianes, Luis A. Fernández-Portillo and Jefferey Sellers

Received: 14 November 2021 Accepted: 24 December 2021 Published: 27 December 2021

Publisher's Note: MDPI stays neutral with regard to jurisdictional claims in published maps and institutional affiliations.

Copyright: (C) 2021 by the author. Licensee MDPI, Basel, Switzerland. This article is an open access article distributed under the terms and conditions of the Creative Commons Attribution (CC BY) license (https:// creativecommons.org/licenses/by/ $4.0 /)$
Climatology Research Group, University of Bayreuth, 95447 Bayreuth, Germany; Etido.Essien@uni-bayreuth.de
Abstract: Urban studies in Nigeria mostly focus on large cities and metropolitan areas, with minimal attention given to sustainable urban development in midsized cities. In this study, we address this knowledge gap and examine the policies and practices driving urban growth in Uyo, a midsized city in Nigeria. Specifically, we evaluate to what extent the prevailing urban governance culture and practices move the city toward or away from being inclusive, safe, resilient, and sustainable - central tenets of UN Sustainable Development Goal (SDG) 11. This study critically explores the strategic and operational approaches deployed by public stakeholders in pursuit of urban development, housing security, and economic and infrastructure development. We find the lack of continuity in commitment to urban infrastructural development projects and a flawed land tenure system that exacerbates housing insecurity are the two most critical challenges to address in attaining the goals of SDG11 in Uyo. The former calls for better fiscal management and adoption of good governance practices across the administrative hierarchy. The land tenure system can be made equitable and less cumbersome by overhauling the 1999 Land Use Act law of the country. Our findings can inform policies to make midsized cities facing similar challenges more inclusive, safe, resilient, and sustainable.

Keywords: urban sustainability; land tenure; urban growth; governance; development; urban planning

\section{Introduction}

The number of people living in urban areas has increased rapidly over the past decades, especially in developing regions of the world [1]. The urban growth in many developing countries has been much faster than the pace of infrastructure development [2]. Furthermore, the growth of small- and midsized cities has been a major contributor to high levels of urbanization [3]. Though Africa's high urbanization rates may look similar to those of other rapidly growing cities, it is important to note that factors that drive urbanization in this continent operate differently from those experienced in developed countries and even in other developing countries $[4,5]$.

Nigeria is one of the largest countries in Sub-Saharan Africa, and has been the third most rapidly urbanizing country after China and India [6,7]. Farrell (2018) contended that most of the emerging cities in Sub-Saharan Africa are in Nigeria. Indeed, 50\% of Nigeria's population resides in urban areas, and the urban population is projected to reach $87 \%$ by $2050[7,8]$, which will require massive infrastructural development $[1,9,10]$.

To date, most of the rapid growth of the cities in Nigeria has happened in an unplanned and unrestrained manner $[9,11]$. This points to the fact that both scientific and policy approaches to sustainable urban growth must urgently address these issues [12,13]. A review of the literature shows different approaches to how changes in technology, economic conditions, and governance influence change in cities as they develop [14] in addition to economic growth, demographic change, and environmental factors [15-17].

Globally, urban studies typically focus on large cities and metropolitan areas, with minimal attention given to sustainable urban development in midsized cities, characterized by widespread urban poverty and degradation of infrastructure $[2,13,18,19]$. Many midsized cities, having been subjected to various infrastructural development projects over the 
years, have experienced uneven urban growth, due to a lack of proper planning that takes into account urban sustainability [20]. Further, most urban studies rely on statistics from the United Nations, World Bank, and African development reports, which rely on official national data. To our knowledge, no other study in the African context has evaluated urban governance-based fieldwork and local data to compare cities' progress towards SDG 11 goals.

In this study, we evaluated the prevailing urban governance culture and practices in Uyo, a midsized city in Nigeria, to identify which governance factors are the most influential in moving the city toward or away from being inclusive, safe, resilient, and sustainablecentral tenets of UN Sustainable Development Goal (SDG) 11-which acknowledges that a multitude of factors can influence urban sustainability both through strong national policy commitments and local governance initiatives $[8,18]$. To this end, we use Uyo as a representative case study to address the following questions: (1) What, if any, strategic and operational approaches are deployed by public stakeholders toward sustainable urban development in Uyo? (2) How do governance practices affect the economic growth, housing security, and infrastructural and urban development in Uyo?

\section{Study Area and Materials}

\subsection{Study Area}

Uyo, the capital of the state of Akwa Ibom, is a midsized city in Nigeria that has been rapidly developing over the past few years due to an increase in allocation of the state oil rent revenue in 2006 [21,22]. The state of Akwa Ibom is located in southeast Nigeria [20], and receives the highest oil rent revenue from the federal government compared to other states in the country, because the state has the highest oil production in the country. This revenue has prompted rapid infrastructural investment within the city [20,23], and has also resulted in the rural-urban and interstate migration of people to the city in search of better living conditions [24]. In 1960, the population of Uyo was 36,061, which grew to 847,480 by 2015 and is estimated to reach 1,135,775 by 2020 (Figure 1), representing a $6 \%$ annual change [25]. Thus, the city's population increased more, when it became the capital of the state in 1987 [24]. The city has attracted citizens from different ethnic groups with varying socioeconomic backgrounds. As it is the capital of Akwa Ibom, substantial financial resources have been channeled toward modernizing the city by successive governmental administrations [20]. Consequently, Uyo has been one of the few cities in Nigeria that has experienced continuous urban growth in recent years [23] (Figure 1). Urban growth in the city is relatively high compared to that of its neighboring cities because there are greater job opportunities and relatively better access to basic social amenities. However, one of the biggest problems in the city is the socio-spatial segregation of communities from different backgrounds [20]. Interactions among the different groups of urban dwellers across the city create challenges as well as opportunities in employment and education [6]. However, poor governance and planning practices have contributed to an increase in social and economic inequalities among its residents [26]. 


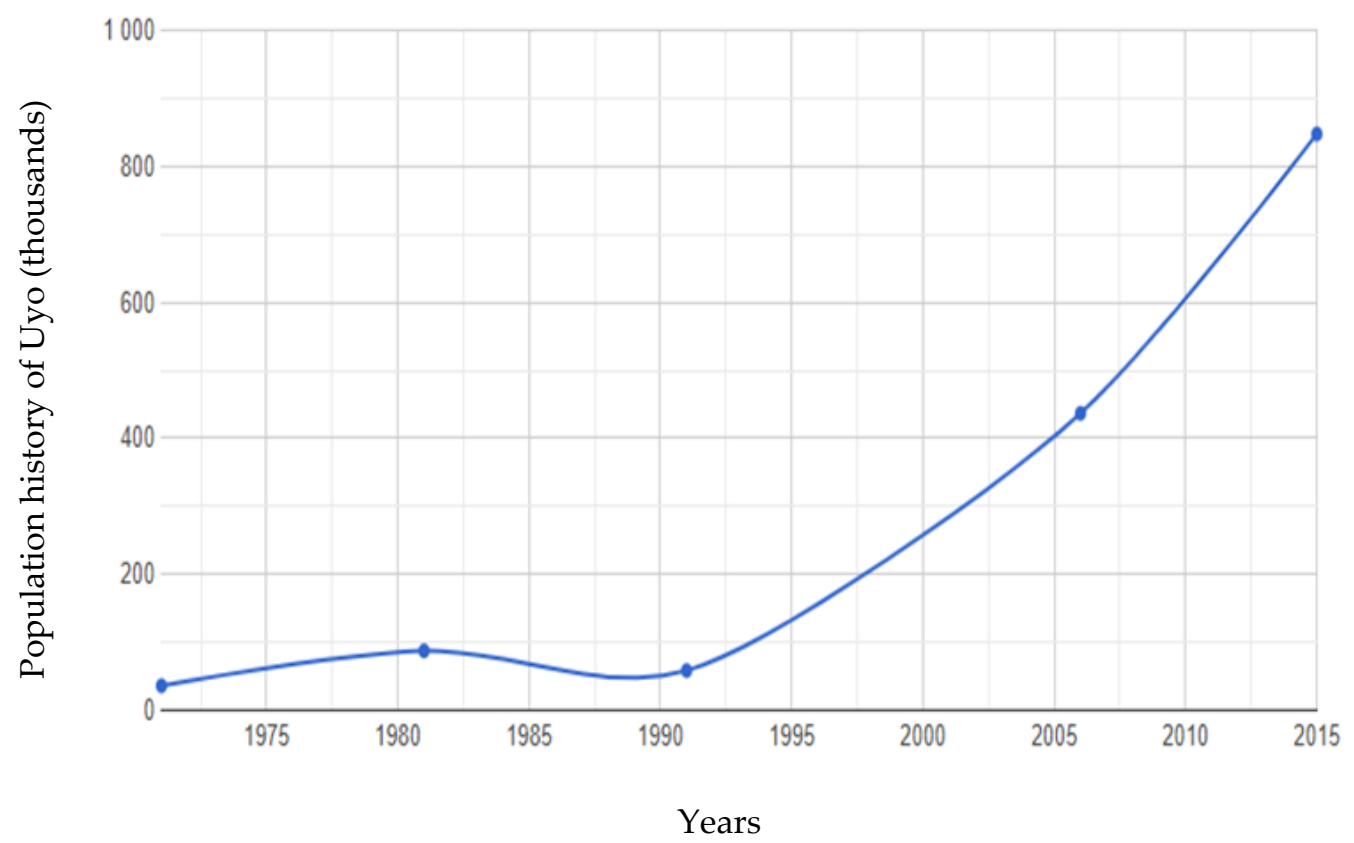

Figure 1. Urban population growth in Uyo (source: NPC, 2015).

\subsection{Data Collection}

In Uyo, qualitative data were examined and presented through a narrative event explored by the interviewers; as well, we reviewed governmental documentation data from each ministry related to urban development, which were examined and are discussed in our results. A structured technique and approach taken from [27,28] were used in formulating our research questions to answer important questions such as: How many projects have been completed, abandoned, or are still in progress since 2000? What is the role of the community in every project planning process? What are the criteria for compensation and what further provision does the government make to assist displaced people? The interview guide questions were presented to the respondents as a checklist and had been given to the respondents before the interviews. The checklist questions were designed as a guide for understanding and interpretation of the data [29].

Furthermore, we reviewed data from the state government's infrastructural development projects of each of the government ministries from 2000 to 2018 to gather more knowledge about the development strategies in the study area, because this was the peak period of infrastructural development in the city [20]. These data include project awards and commissioning, fund allocation to different sectors, housing schemes and policies, population growth, urban infrastructural development and maintenance plans, which were compiled to assess the developmental trend and future sustainable plans [8,30]. We critically studied all of the gathered information to evaluate to what extent the policies were aligned with the guidelines stated in SDG 11 to make cities inclusive, safe, resilient, and sustainable.

\section{Method}

\subsection{Structured Interviews}

The data for this research were collected through structured interviews, fieldwork, and a reconnaissance survey of the city. We followed the approach suggested by [27], that 10 to 20 in-depth interview cases are adequate to obtain information. However, a higher number of respondents could be used if more respondents were accessible and willing to take part in the interview process [28]. As well, we visited different infrastructural facilities in Uyo's urban and suburban areas to establish detailed knowledge of the existing urban growth. We also reviewed governmental documents to assess the urban governance and policies in the city. 
First, we conducted discussions and interviews with key urban policymakers to obtain information about government policies and planning in response to the rapid growth of the city. During this process, the focus was on six target governmental ministries related to urban planning, policy, and economic development, and 60 public participants (Table 1). These were the Ministry of Works, the Ministry of Land and Housing, the Ministry of Economic and Rural Development, the Ministry of Urban and Town Planning, the Ministry of Internal Revenue, and the Ministry of Information and Strategy. We identified one key respondent from each of these ministries. The criteria for the selection of these key respondents were based on their rank (directorate level) and the number of years they were employed in the ministry. The respondents were people that had at least twenty-five years' experience working with different governmental heads.

Table 1. List of key respondents in different sectors.

\begin{tabular}{ccc}
\hline & Key Respondents & Positions \\
\hline 1 & Ministry of Information and Strategy & Director \\
\hline 2 & Ministry of Work & Director \\
\hline 3 & Ministry of Land and Housing & Director \\
\hline 4 & Ministry of Economic and Rural development & Director \\
\hline 5 & Ministry of Urban and Town Planning & Director \\
\hline 6 & Ministry of Internal Revenue & Director \\
\hline 7 & Community Stakeholders & Leaders \\
\hline 8 & Academic sector & Researchers \\
\hline 10 & Commercial Businesses & Business owners \\
\hline 11 & Public servants & Level 12 \\
\hline
\end{tabular}

\subsection{Qualitative Data Analysis}

The interpretation and grouping of the classified data were done following theoreticalbased models proposed by [31]. The objective was to group different classes of data to obtain information about factors that influence urban sustainability in the study area. The interview was structured with insightful questions and guided checklist questions. We began each interview by elaborating on the objective of the interview to the respondent, to inform the respondent on how the generated data would be used to respond to our research questions. We used a three-step data framework of grouping data into different categories [31]. This approach separates data that are similar to each other based on respondents having the same questions $[27,28]$. Most of the responses were similar, and we computed them to generate data. We grouped similar data into the same categories and extracted vital information from the data. Our findings are discussed in detail in the sections below.

\section{Results and Discussion}

\subsection{Economic Growth in Uyo}

Sustainable economic growth can drive high production levels, create modest jobs for all and encourage entrepreneurship [8]. This would entail accountability and responsibility that would bring changes within the different economic sectors in various communities and economic enlightenment to handle its impact on society and urban areas [8]. In Uyo, according to the interview results (Figure 2), economic reforms and infrastructural development have transformed the city into a rapidly growing urban area due to high revenue obtained from the extraction of its main natural resource (crude oil) [20]. These revenues, channeled from the federal government, have been the primary source of income driving the state economy for years, even though the state government had created a few 
industries within the city neighborhoods, such as a paper mill in Oku lboku and a paint factory in Etinan [32]. These industries create employment for the young labor force, and also aid in sustaining the economic growth of the city and the state. Moreover, a significant chunk of the generated revenue is reinvested in the city because of its position as the state capital based on our government data report.



Figure 2. Factors influencing urban growth in Uyo.

Economic growth and reform (Figure 2) have also created employment in different sectors of the city economy (Figure 3), but manufacturing is among the slowest-growing sectors, despite most of the labor force increasing (Figure 3). Studies have shown that manufacturing industries managed by the governments in some African countries have struggled in contemporary times [5], even though there have been improvements in the education and informal economic sectors (Figure 3). These results were attributed to governmental decisions (Figure 2), the frequent turnover of governmental administrations, poor accountability, and the collapse of state-owned industries (Figure 2). This probably explains why the Nigerian government has recently embarked on large-scale privatization of state assets built during the post-independence era [33].

In response to unplanned urban growth in the city, the state's masterplan was redesigned toward achieving its urban development plans [20]. However, though few heads of administrations have focused on completing the projects that were already initiated prior to their terms, most instead emphasize creating small-scale industries such as pencil, toothpick, and cassava processing mills to provide quick employment opportunities for the growing labor force and export purposes. However, because of poor product quality and inconsistency in these industries, the goods manufactured with these raw materials are rarely used within the state, being more expensive than comparable products on the market, and are not exported as intended. Furthermore, the funds generated from these companies are misused [34]. 


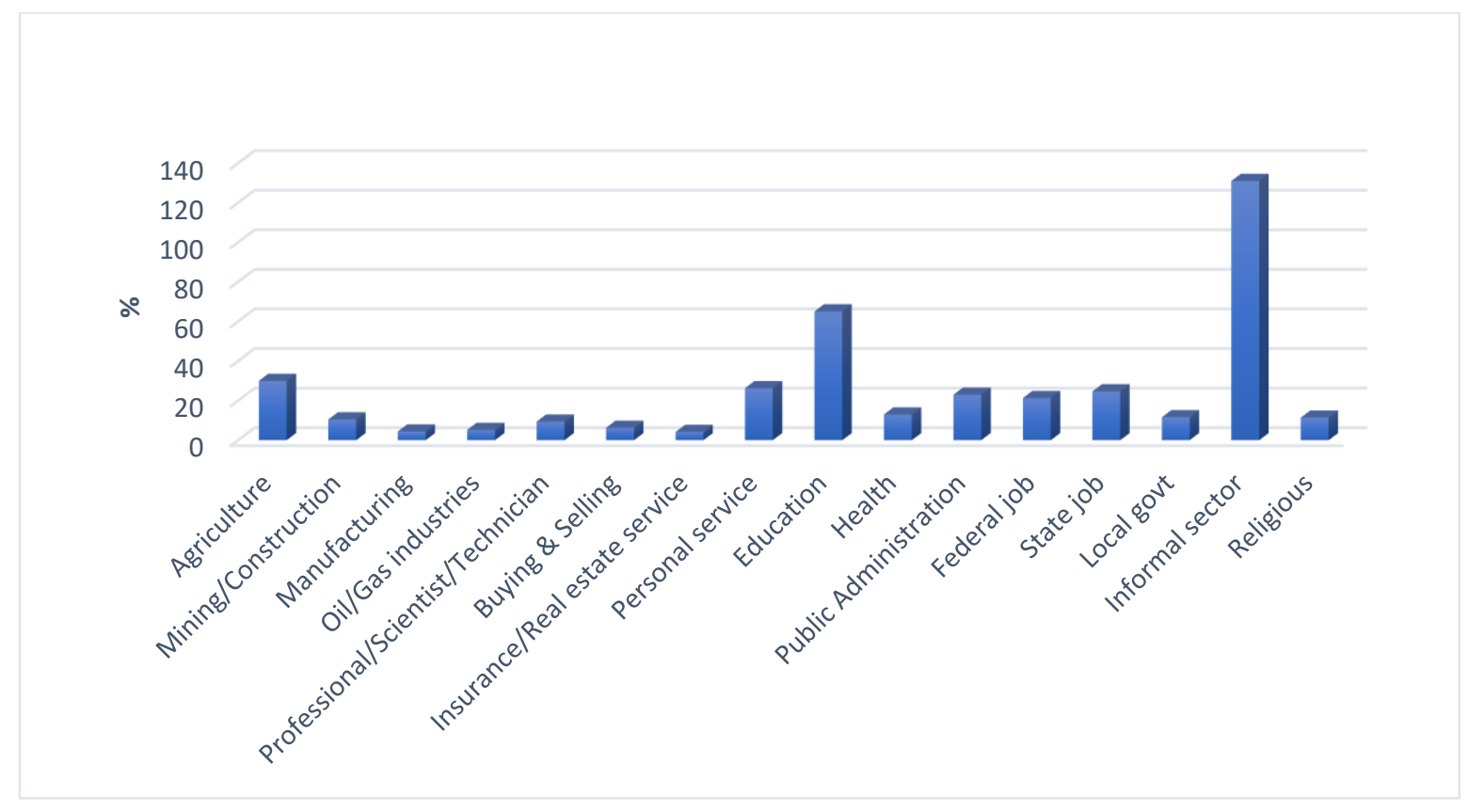

Figure 3. Employment sectors in Uyo (source: Essien \& Samimi 2021).

Consequently, these industries usually fold up at the end of the tenure of the administration that opened them due to changes in management by the new government (Figure 2). Based on our respondents' data, governmental decisions (Figure 2) have hindered the successful, sustained diversification of the city's economy, which is essential to attain SDG 11. Our data show (Figure 2) that governmental heads channel most of the revenue generated from natural resources to investment in small-scale projects with different products, such as wine, tomato, and flour mill industries. Although these industries were meant to alleviate poverty by providing employment to citizens, they were also designed for export to boost the economy [35]; however, these goals do not appear to have been achieved and do not support SDG 11.3, which entails sustainable planning and management in all countries. To address these issues, government administrations need to focus more on the continuity of governmental projects and the regulation of small-scale businesses in urban areas. This would also help governmental heads assess how their economic growth plans align with SDG 11.A, which endorses positive economic growth.

\subsection{Large-Scale Infrastructural Development in Uyo}

Sustainable infrastructure development must be inclusive and respect human rights; that is, such infrastructure must meet the needs of the poor by increasing infrastructure access, supporting general poverty reduction, and positively impacting GDP per capita [35]. However, the development trend in Uyo shows that the city is yet to follow any of the strategies that may lead to sustainable and just urban growth in the provision of energy, water, and affordable housing [36]. Based on the reviewed governmental data, there are no plans to provide a structured public transportation system in the city to reduce traffic congestion. The government efforts instead center on improving road infrastructure and providing free education for primary and high school levels.

According to some of the governmental respondents, a major urban transition of Uyo depends on infrastructure development, but sustaining this development is a major concern for stakeholders. There are many urban sustainability problems in Nigeria, such as poor energy supply, unregulated water supply, indiscriminate sewage disposal, unpaved streets, and loss of urban vegetation [37]. Due to their importance for quality of life and economic development, some administrations have tried to mitigate some of these problems. For example, past administrations invested more in roads, yet the city is still congested because 
infrastructure for public transportation, such as buses and railways, has been neglected. The respondents highlighted that most of the large-scale infrastructure in the state does not serve its intended purpose.

Based on our governmental data, the state invested USD 1 billion into building a power plant for reliable energy supply to the city, but abandoned the project after a change in administration, claiming the project went over budget. Hence, parts of the city have no electricity, while others experience frequent outages. Most occupants and companies use alternative means of power supply, such as power generators, causing a lot of noise and air pollution [38]. In addition, most government-sponsored projects take much longer than scheduled to complete because of poor planning and lack of proper oversight.

Furthermore, some respondents are concerned that most of the large-scale investments in the state do not receive any capital return. Based on our review of the governmental data, the administration invested USD 52.3 million in buying the first state-owned commercial airline (Ibom Air) in the country, rather than maintaining the recently constructed airport that was aimed to function as an international airport. Due to the state's geographical location, the airport was to serve not only local travelers but also international travelers of the southern region of Nigeria. The most pressing question is what are the existing plans and policies to sustain such investments from collapsing at the end of each government's tenure. Policies that encourage such investments tend not to be linked with the SDG 11.3 target.

\subsection{Housing Security in Uyo}

The very first target of SDG 11 stipulates ensuring access for all to adequate, safe and affordable housing and basic services, and upgrading slums by 2030 [8]. The UN report states that the provision of affordable housing and shelter is a fundamental human right, and it is considered an essential requirement of better living conditions [39]. Although major inequalities exist among many urban dwellers, there is a critical need for better housing conditions in developing countries [39], particularly with their rapidly growing urban centers and populations, adjudged to be the fastest growing in the world [40].

Uyo is one of the few capitals in Nigeria where a remarkably high proportion of state population resides in the city [24], and according to the respondents, the city has experienced drastic population growth due to migrants coming from poorer parts of the country in search of better opportunities (Figure 2). Consequently, housing costs are high in the city center, and this has generated heterogeneous patterns of built-up areas (Figure 4). Public housing programs meant for middle-income earners and civil servants are grossly insufficient to meet demand (Figure 5); also, qualifying for such housing means overcoming many bureaucratic hurdles $[35,40]$. This situation results in people sourcing alternative means of housing such as converting cargo containers meant for importing and exporting goods to dwellings and shops on the suburban fringes of the city (Figure 4).

In our review, many of the respondents adjudged the poor housing security in Uyo to formal residential buildings often being demolished to open up space for the construction of various public infrastructure projects, such as the construction of a recreation center (Ibom Plaza) and an overpass (Atiku Abubakar). Although the development of the overpass has helped boost economic integration of the city with other states and eased traffic, many people were forcefully displaced and poorly compensated for the loss of their homes and properties for development purposes (Figure 2). This resulted from the 1999 Land Use Act law of the country, which posits that all land within the state belongs to the government [41], and as such, the compensation paid to such individuals only reflects the value of the existing building structures or agricultural crop grown on the land. 


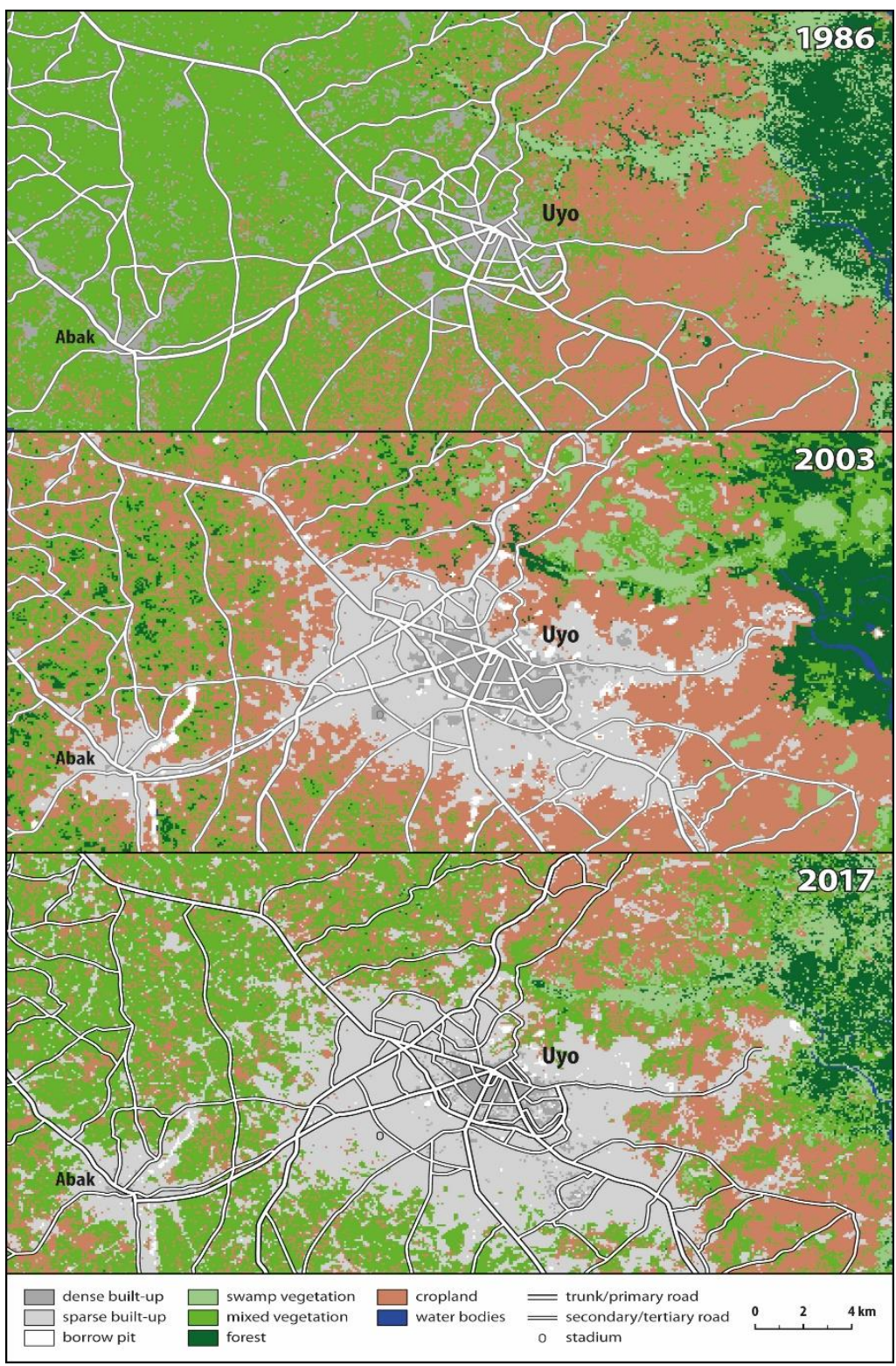

Figure 4. Land cover maps of Uyo for 1986, 2003, and 2017 (source: Essien \& Samimi, 2019).

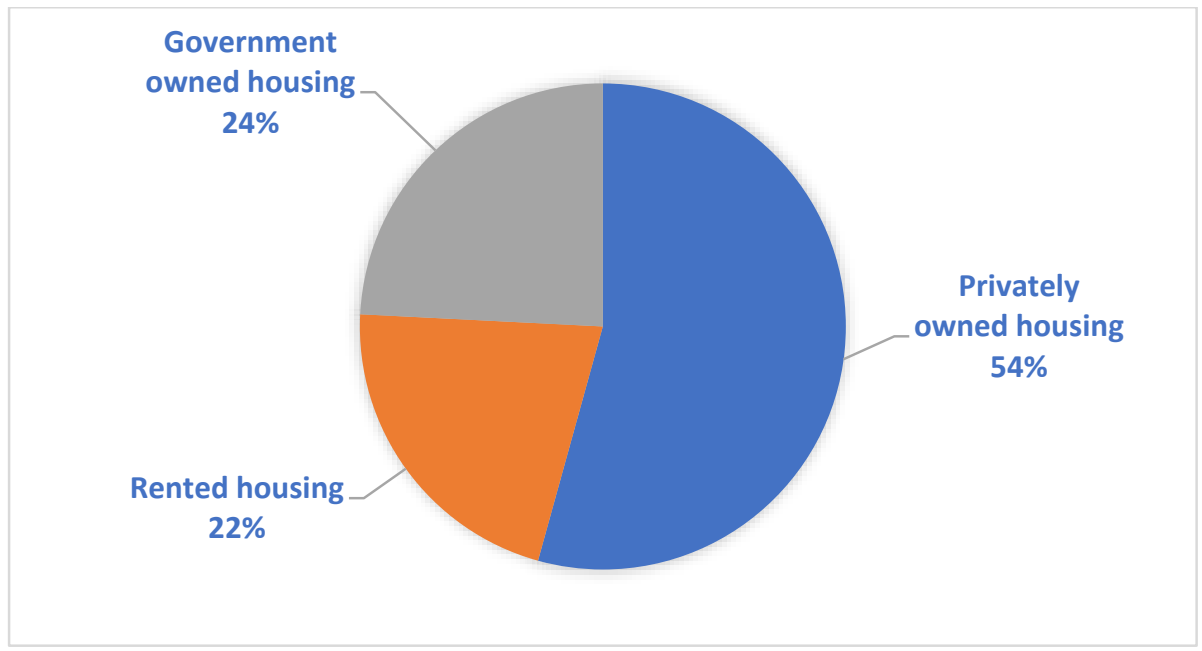

Figure 5. Breakdown of housing type in Uyo. 
Based on data from respondents in the governmental ministries, there have been government initiatives in the past to build affordable housing units for the civil servants in the state, but these initiatives were hijacked by corrupt politicians who claimed to be civil servants to buy the houses and resell them at a higher rate to the general public. Therefore, in addition to the provision of affordable housing for low-income citizens through governmental funding, there should also be legislation to regulate housing prices within the urban centers [35]. However, at present, there is not even an affordable housing plan for non-governmental and low-income earners. This is contrary to SDG 11.1, which supports affordable and adequate housing for all.

\subsection{Governance Practices}

Urban governance in Nigeria is highly compartmentalized, without adequate interdepartmental collaboration [42]. Moreover, the state planning authority (i.e., the Ministry of Town Planning and Rural Development (MTPRD)) rarely adheres to its stated environmental planning ethics or follows its existing master plan [43]. Though this ministry was tasked with planning and ensuring that every approved building meets specified quality levels and standards, most buildings are approved without proper scrutiny. Importantly, it is expected that more than $60 \%$ of the urban centers to be opened in Nigeria by 2050 have yet to be planned [6]. This calls not only for provision of strict planning laws but also their effective enforcement by public stakeholders to regulate urban infrastructural development [40].

According to the information gathered from the governmental ministries and related literature of many other developing countries [5,40], Uyo follows a system of disbursing funds from the state to the local governments, and this limits the financial independence of local governments [44]. Generally, even though the state generates revenue from taxpayers from the local governments under its jurisdiction, they still depend largely on federal funds. The state government usually requests financial support from the federal government for large-scale projects and sometimes even for minor projects, and in turn, the federal government usually sources foreign investment for the state government. This support may come in the form of a loan, depending on the bilateral relationship with the foreign country [45]. Initially, foreign loans were meant to provide support to huge projects that cannot be financed by the state, but at present, such loans are being used to service major and minor infrastructural projects within states depending on the governmental head decision (Figure 2). However, the focus should instead be on generating funds within the state to support, at least, minor projects rather than collecting foreign loans. Funds can be generated within the community if there is a good and transparent system of tax collection from high-, medium-, and low-income earners [46].

The majority of the respondents are of the view that beyond tax accountability [46], fiscal policy and budget management also need to become more transparent at all levels of government. Proper assessment should be done by the federal government before releasing funds to the state governments for project implementation, and continuous project auditing should be done to ensure that these projects are executed at the planned time to achieve their purpose. This will help to achieve sustainable infrastructural development goals that alleviate poverty for vulnerable people [30], reduce misuse of public funds for unsustainable projects that burden the governments with debt they may not repay, and/or avoid establishing tariffs that end users cannot afford [30,36].

A comprehensive review of our respondents' data from the different governmental ministries shows that the Nigerian system of governance is characterized by turnover of administrations every four years, and this is mostly accompanied by a change in planning and administrative policy by the incoming heads of the administrations (Figure 2). It is common for government heads to squander public funds on their pet projects (Figure 2). For example, a previous government head liked golf and decided to build a golf resort in the city just because of his love of golf, while his predecessor liked football and decided to build one of the best stadiums in Nigeria (Godswill Akpabio Stadium) although the 
city already had a stadium that could have been renovated or restructured, using the vast amount of bare land surrounding it for expansion. Instead, this old stadium was simply abandoned and is no longer maintained. If the old stadium had been renovated instead, the funds used towards building the new stadium could have been channeled into other needed infrastructure developments such as industries capable of creating more employment opportunities for the majority of the city's urban dwellers, who work in unskilled jobs [47].

Furthermore, based on the view of governmental stakeholders, even sound infrastructure developments often fall victim to rivalry among political parties. A new government might simply discontinue the project it inherited from the previous administration, claiming corruption or mismanagement, and spend the first two years of its administration investigating its predecessor's governmentally awarded contracts. Often, there is also incentive to re-award these projects to political allies or cronies. All these issues easily distract an incoming administration from delivering good governance to its constituents, resulting in incomplete infrastructural development projects in the city [43]. This approach needs to be reviewed because it has restrained most of the cities not only in Nigeria but across Sub-Saharan Africa from being appropriately developed [5].

Finally, as asserted by some of the respondents (Figure 2), the opinions of community leaders are rarely taken into consideration when making urban development plans within the state. Community leaders should act as a direct link between the people and the government when implementing urban development projects [48], yet these leaders are hardly consulted. There is evidence of productive collaborations among community leaders, government officials, and private investors in cities such as Navi Mumbai in India, Pudong in China, and New Town in Vietnam, bringing their respective cities closer to the community dwellers to achieve unified development [48]. This system of governance should be adopted in Uyo and SDG 11.A should be integrated into every piece of legislation and policy at all levels of the government in Nigeria.

\subsection{Toward Sustainable Urban Growth in Uyo}

In 2015, the United Nations (UN) member states adopted 17 goals (referred to as the Sustainable Development Goals, SDG) as part of the vision of the 2030 Agenda for Sustainable Development, and a period of 15 years was proposed to achieve these SDGs [8]. Although progress in achieving these goals has been made in many cities across the globe, there are many more that have yet to take any tangible action [8]. With just a few years left to achieve these goals, during the 2019 summit, world leaders called for speedy action to be taken and institutions to be strengthened to achieve these SDGs by the target date of 2030 [8].

Many countries in Sub-Saharan Africa face enormous challenges in achieving SDGs. Never-ending power struggles and contestation of authority distract the elected governments from implementing good governance in cities [49]. Likewise, in Uyo, there is an urgent need for tighter interaction and coordination among respective urban governance entities. Decision-makers should always try to properly manage friction during the transition of power between governmental administrations to promote sustainable infrastructural development. This will help increase productivity [35], reduce the number of incomplete projects within the state, and promote unification in achieving the overall goals of every project. Strategies for managing state-owned industries should be designed to achieve highquality and affordable products. These sustainability strategies will also help to eliminate the chances of industries and infrastructure collapsing as a result of poor management or governance.

Currently, in Nigeria, the land-use law provides the government sovereignty over all land in the state, neglecting the communal and land tenure system of land ownership [41,50]. Land can only be owned after proper land registration at the Ministry of Land and Housing, although the associated administrative processes mean years of bureaucratic hurdles [40]. Citizens with little knowledge of the law or limited financial means to register their land 
may begin building structures for shelter without proper registration and approval. The provisions of SDG 11 should be integrated into legislation and policy at all levels of government in Nigeria. This should include rules and regulations that govern land use planning practices in the country. Regarding this aspect, the 1999 Land Use Act law that governs land in the country needs to be reviewed. A systemic approach to urban governance that can educate the people, speed up land registration processes, and promote collaboration among different departments toward moving the city toward SDG 11.A should be encouraged.

Housing challenges have been largely overlooked within the city (Figure 2). The state government should aim at providing housing security for urban dwellers, especially the poor and displaced people. Housing policy should be designed and implemented by the Ministry of Land and Housing. Housing rent should be regulated and made affordable to the public without constant increases, which will help to reduce the existing level of inequality among urban dwellers $[35,40]$. The government should properly monitor the implementation of all these strategies to ensure that the aims and objectives of SDG 11.1 are achieved in the city.

Poor accountability and lack of transparency in revenue collection [46] and implementation of infrastructural projects have increased the fiscal challenges in Uyo. An efficient and transparent system of tax collection from businesses and workers, as well as the remitting of these taxes to the government, should be designed and implemented by the ministry of internal revenue. These taxes will help to boost the city's economy, as well as the development and maintenance of some infrastructural facilities.

\section{Conclusions}

In this study, we examined the urban governance policies and practices in Uyo, a midsized city in Nigeria, in light of SDG 11: Sustainable cities and communities. This study agrees with other related scientific studies, and it is the first in Sub-Saharan Africa to analyze urban governance towards sustainable development. Specifically, we analyzed the influence of governance practices in the city on infrastructural development, housing security, economic growth, and urban development. Our findings show that the main causes of the poorly planned development in the city are: (i) the friction between successive governmental administrations, (ii) the lack of allocated funds for housing security and the maintenance of many existing infrastructures, and (iii) the lack of transparency and accountability in revenue collection and execution of projects within the city. Using Uyo as a case study, we highlighted the specific challenges that many other midsized cities in Sub-Saharan Africa and other developing countries share. We also identified potential ways to address these challenges in creating healthy, just, and equitable environments with a high quality of life from the local to the national level.

Funding: This research was funded by the German Academic Exchange Service (DAAD), grant number 91666076.

Data Availability Statement: Not applicable.

Acknowledgments: I would like to acknowledge the support of Burak Güneralp for his many constructive comments and contributions that helped to improve this paper. I am also grateful for the support and advice from Cyrus Samimi.

Conflicts of Interest: The author declares no conflict of interest.

\section{References}

1. Montgomery, M. The urban transformation of the developing world. Science 2008, 319, 761-764. [CrossRef]

2. Nyström, M.; Lindgren, E.S. Sustainable Urban development and environment. In A Research Agenda for Africa 2005; SIDA: Stockholm, Sweden, 2005.

3. Güneralp, B.; Meredith, R.; Billy, U.; Elizabeth, A.; Seto, K. Trends in urban land expansion, density, and land transitions from 1970 to 2010: A global synthesis. Environ. Res. Lett. 2020, 15, 044015. [CrossRef] 
4. Güneralp, B.; Shuaib, L.; Hillary, M.; Susan, P.; Karen, S. Urbanization in Africa: Challenges and opportunities for conservation. Environ. Res. Lett. 2017, 13, 015002. [CrossRef]

5. Pieterse, E. The Potential for Sustainable Urbanisation in Africa; Centre for Cities; University of Cape Town: Cape Town, South Africa, 2019.

6. Avis, W. Urban Expansion in Nigeria. K4D Helpdesk Report 692; Institute of Development Studies: Brighton, UK, 2019.

7. UN DESA. World Urbanization Prospects 2018: Highlights. UN DESA. 2019. Available online: https://population.un.org/wup/ Publications/Files/WUP2018-Highlights.pdf (accessed on 21 April 2021).

8. United Nation Development Programme (UNDP). 2018. Available online: www.ng.undp.org/content/nigeria/en/home/ sustainable-development-goals (accessed on 13 June 2021).

9. Farrell, K. An Inquiry into the Nature and Causes of Nigeria's Rapid Urban Transition. Urban Forum 2018, 29, 277-298. [CrossRef]

10. McDonnell, J.; MacGregor-Fors, I. The ecological future of cities. Science 2016, 352, 936-938. [CrossRef]

11. The Cities Alliance; Foundation for Urban Development in Africa. The Legacy of Akin Mabogunje; The Cities Alliance: Washington, DC, USA, 2007.

12. Ramaswami, A.; Russell, G.; Culligan, J.; Sharma, R.; Kumar, E. Meta-principles for developing smart, sustainable, and healthy cities. Science 2016, 352, 940-943. [CrossRef]

13. Wachsmuth, D.; Cohen, D.; Angelo, H. Expand the frontiers of urban sustainability. Nature 2016, 536, 391-393. [CrossRef]

14. Swilling, M.; Hajer, M. Governance of urban transitions: Towards sustainable resource efficient urban infrastructures. Environ. Res. Lett. 2017, 12, 125007. [CrossRef]

15. Singh, S.; Kennedy, C. Estimating future energy use and $\mathrm{CO}_{2}$ emissions of the World's cities. Environ. Pollut. 2015, 203, 271-278. [CrossRef]

16. Kennedy, C.; Ibrahim, N.; Hoornweg, D. Low-carbon infrastructure strategies for cities. Nat. Clim. Chang. 2014, 4, 343-346. [CrossRef]

17. Kennedy, C.; Steinberger, J.; Gasson, B.; Hansen, Y.; Hillman, T.; Havránek, M.; Pataki, D.; Phdungsilp, A.; Ramaswami, A.; Mendez, G. Greenhouse gas emissions from global cities. Environ. Sci. Technol. 2009, 43, 7297-7302. [CrossRef] [PubMed]

18. Bai, X.; Surveyer, A.; Elmqvist, T.; Gatzweiler, F.W.; Güneralp, B.; Parnell, S.; Prieur-Richard, A.-H.; Shrivastava, P.; Siri, J.G.; Stafford-Smith, M.; et al. Defining and advancing a system approach for sustainable cities. Curr. Opin. Environ. Sustain. 2016, 23, 69-78. [CrossRef]

19. Seto, K.; Golden, J.; Marina, A.; Turner, L. Sustainability in an urbanizing planet. Proc. Natl. Acad. Sci. USA 2017, 114, 8935-8938. [CrossRef]

20. Essien, E.; Samimi, C. Detection of Urban Development in Uyo (Nigeria) Using Remote Sensing. Land 2019, 8, 102. [CrossRef]

21. Egugbo, C.C. Resource Control and the Politics of Revenue Allocation in Nigerian Federation. Int. J. Arts Humanit. 2016, 5, 186-201. [CrossRef]

22. Onuigbo, R.; Innocent, E. State Governors and Revenue Allocation Formula in Nigeria: A Case of the Fourth Republic. Int. J. Account. Res. 2015, 2, 14-36. [CrossRef]

23. Akpan-Ebe, N.; Udotong, R.; Ekpenyong, E. Ecological Consequences of Urbanization of Uyo Capital City, Akwa Ibom State, Nigeria. J. Agric. Ecol. Res. Int. 2015, 3, 1-12. [CrossRef]

24. National Population Commission. Annual Population Projection. Federal Republic of Nigeria. 2015. Available online: http: / / population.city/nigeria/uyo/ (accessed on 18 May 2021).

25. Africapolis, I. Update, West African Studies; OECD Publishing: Paris, France, 2019.

26. Israel, U.E. Urbanization and Conflict: A Study of Uyo, 1900-2015. Afr. J. Hist. Archaeol. 2018, 3, 35-49.

27. Miles, B.; Huberman, M. Qualitative Data Analysis; Sage Publications: Newbury Park, London, UK, $1994 ;$ pp. $228-245$.

28. Guest, G.; Bunce, A.; Johnson, L. How Many Interviews Are Enough? Field Methods 2016, 18, 59-82. [CrossRef]

29. Amin, M. The impact of heritage decline on urban social life. J. Environ. Psychol. 2018, 55, 34-47. [CrossRef]

30. Aina, Y.; Wafer, A.; Ahmed, F.; Alshuwikhat, M. Top-down sustainable urban development? Urban governance transformation in Saudi Arabia. Cities 2019, 90, 272-281. [CrossRef]

31. Jarah, S.H.A.; Zhou, B.; Abdullah, R.J.; Lu, Y.; Yu, W. Urbanization and Urban Sprawl Issues in City Structure: A Case of the Sulaymaniah Iraqi Kurdistan Region. Sustainability 2019, 11, 485. [CrossRef]

32. Akpabio, M.; Akpan, N. Governance and Oil Politics in Nigeria's Niger Delta: The Question of Distributive Equity. J. Hum. Ecol. 2010, 30, 111-121. [CrossRef]

33. Bakre, O.M.; Lauwo, S. Privatisation and accountability in a "Crony capitalist" Nigerian state. Crit. Perspect. Account. 2016, 39, 45-58. [CrossRef]

34. Ovunda, A. Burning Issues in the Nigeria Tax System and Tax Reforms on Revenue Generation: Evidence from Rivers State. Int. J. Financ. Account. 2018, 7, 36-48.

35. Organisation for Economic Co-operation and Development (OECD). Economic Diversification in Africa: A Review of Selected Countries. Available online: https://www.oecd.org/development/investmentfordevelopment/economicdiversificationinafricaa reviewofselectedcountries2011.htm (accessed on 25 October 2020).

36. Deakina, M.; Alasdair, R. Sustainable urban development: Use of the environmental assessment methods. Sustain. Cities Soc. 2013, 10, 39-48. [CrossRef] 
37. Onibokun, A.; Faniran, A. Urbanization and Urban Problems in Nigeria. Urban Research in Nigeria. 2006. Available online: http: / / www.books.openedition.org/ifra (accessed on 7 January 2021).

38. Montes-González, D.; Vílchez-Gómez, R.; Barrigón-Morillas, M.; Atanasio-Moraga, P.; Rey-Gozalo, G.; Trujillo-Carmona, J. Noise and Air Pollution Related to Health in Urban Environments. Multidiscip. Digit. Publ. Inst. Proc. 2018, 2, 1311. [CrossRef]

39. Tusting, L.; Donal, B.; Graham, A.; Ewan, C.; Richard, C.; Michael, D.; Seth, F.; Harry, G.; Jakob, K.; Charles, M.; et al. Mapping changes in housing in sub-Saharan Africa from 2000 to 2015. Nature 2019, 568, 391-394. [CrossRef]

40. Mahendra, A.; Seto, K. Upward and Outward Growth: Managing Urban Expansion for More Equitable Cities in the Global South; Towards a More Equal City; World Resources Report: London, UK, 2019.

41. Otubu, A. The Land Use Act and Land Administration in 21st Century Nigeria: Need for Reforms. J. Sustain. Dev. Law Policy 2018, 9, 80-108. [CrossRef]

42. Smith, R.; Wiek, A. Achievements and opportunities in initiating governance for urban sustainability. Environ. Planning. C Gov. Policy 2012, 30, 429-447. [CrossRef]

43. Essien, E.; Samimi, C. Evaluation of Economic Linkage between Urban Built-Up Areas in a Mid-Sized City of Uyo (Nigeria). Land 2021, 10, 1094. [CrossRef]

44. Nkechi, O. New Revenue Sharing Formula Clamour by the Nigerian State Governors: Propelling Factors and Matters Arising Public Policy Adm. Res. 2013, 3, 27-36.

45. Investment Guide 2017/2018. Available online: https://www.africalegalnetwork.com/wp-content/uploads/2017/02/NigeriaInvestment-Guide-2018 (accessed on 14 March 2021).

46. Evans, O. Fiscal Discipline, Financial Development \& Economic Growth in Nigeria. In Dynamics of Fiscal and Monetary Policies in ECOWAS Countries; Nwaogwugwu, C.I., Ed.; University of Lagos Press: Lagos, Nigeria, 2020.

47. Eni, D.; Ubong, E. Poverty and Environmental Degradation in Uyo Urban, Akwa Ibom State, Nigeria. Afr. J. Educ. Stud. Math. Sci. 2008, 6, 56-64. [CrossRef]

48. Gotsch, P.; Peterek, M. New Settlements in the South-Urban Models for the 21st Century? In Proceedings of the International Conference Megacities III: Action Models and Strategic Solutions, Wesseling, Germany, 24-26 November 2003.

49. Schuberth, M. Hybrid Security Governance, Post-election Violence and the Legitimacy of Community-based Armed Groups in Urban Kenya. J. East. Afr. Stud. 2018, 12, 386-404. [CrossRef]

50. Nuhu, M.; Aliyu, A. Compulsory Acquisition of Communal Land and Compensation Issues: The Case of Minna Metropolis. In Proceedings of the FIG Working Week 2009 Surveyors Key Role in Accelerated Development, Eilat, Israel, 3-8 May 2009. 